Egyptian J. of Nutrition Vol. XXXV No. 2 (2020)

\title{
A new functional whey beverage, containing calcium and Date syrup (Dibs)
}

\author{
${ }^{\star}$ Rehab H. Gab-Allah and ${ }^{\star \star H e b a ~ A . ~ S h e h t a ~}$ \\ *Dairy Technology Department, Food Technology \\ Research Institute, A.R.C., Giza, Egypt. \\ ${ }^{* *}$ Regional Center for Food and Feed, A.R.C., Giza, Egypt.
}

\begin{abstract}
The study is about the use of by-products of the food industry that have functional and biological properties such as cheese whey and eggshell in the production of whey beverages. Fermented whey beverage was prepared by blending $1 \%$ eggshell, $1 \%$ egg yolk, $0.1 \%$ CMC and $0.01 \%$ vanilla with sweet whey. Bifidobacteriumanimals ssp. LactisBb-12 was used as a probiotic organism. Date syrup (Dibs) was used as a natural sweetener in different levels 10, 12.5 and $15 \% \mathrm{v} / \mathrm{v}$ of the beverage and analyzed for various physicochemical, microbiological properties as well as sensory properties for its overall acceptability during cold storage at $4 \pm 1^{\circ} \mathrm{C}$ for 21 days. The obtained results indicated that $\mathrm{pH}$ values were decreased graduallyduring cold storage while the viscosity was increased. The viability of Bifidobacteriumanimals ssp. Lactis remained high up to 14 days then started to decrease. The study revealed that the fermented whey beverage containing $12.5 \%$ dibs showed superiorityin almost all physicochemical, microbialand sensory properties as compared to the other treatments
\end{abstract}




\section{Rehab H. Gab-Allah and Heba A. Shehta}

\section{Introduction}

Specifically, beverages are by a wide margin the most dynamic functional foods category because of (i) comfort and probability to meet consumer demands for container contents, size, shape, and appearance; (ii) simplicity of distribution and better storage for refrigerated and shelf-stable products; (iii) extraordinary chance to fuse attractive supplements and bioactive mixes compounds (Sanguansri and Augustin, 2009 andWootton-Beard and Ryan, 2011). The different types of commercially available products could be grouped as follows: (1) dairy-based beverages including probiotics and minerals/ $\omega-3$ enriched drinks, (2) vegetable and fruit beverages, and (3) sports and energy drinks Maria et al., (2014).

Whey, a valuable dairy by product contains half of the milk solids and is a rich source of lactose, water soluble vitamins, minerals, and immunologically active proteins. It contains about 50 $55 \%$ total milk solids, $70 \%$ of milk sugar, $20 \%$ of milk proteins and 70 $90 \%$ of minerals and almost all water soluble vitamins especially vitamin B complex and vitamin CDurham et al., (1997), Sinhaet al.,(2007).

Probiotics are defined as 'live micro-organisms, which when consumed in adequate amounts confer a health benefit on the host' FAO/WHO,(2001).Probiotic microorganisms are generally LAB belonging to the species Lactobacillus acidophilus, $L$. gasseri, $L$. helveticus, L. johnsonii, L. paracasei, L. reuteri, L. plantarum, $L$. rhamnosus, and $L$. fermentum, while members of the genus Bifidobacterium are also used, e.g., Bifidobacteriumbifidum, $B$. 
Egyptian J. of Nutrition Vol. XXXV No. 2 (2020)

Iongum, B. animalis, and B. breve (Tamimeet al., 2005 and Castro et al., 2015 and Linares et al., 2016).

A huge amount of research describes the role of theBifidobacterium genus in promoting human health, such as antihypertensive, anti-inflammatory, and anti-diabetic, anti-oxidative, immune-modulatory, anti-cholesterolemic, or microbiome modulation Linares et al., (2017).

Calcium (Ca) is one of the important macronutrients necessary for the normal functioning of the human body. Calcium is not only the major component of bones and teeth, but it also participates in the regulation of hormone secretion and activation, muscle contraction, neuronal conduction via ion channels, regulation of inflammatory processes, maintaining the permeability of cell membranes, and many others Driet al.,,(2011).Some studies showed beneficial effects of dietary calcium on lipid metabolism, insulin resistance, and abdominal obesity of persons with metabolic syndrome (Jacqmainet al.,2003 and Lorenzenand Astrup, 2011). Natural $\mathrm{Ca}$ sources are of interest because they contain not only $\mathrm{Ca}$ but also other elements (e.g., Sr and F), which may have a positive effect on bone metabolism Olgunet al., (2015).

Chicken eggshell is a waste material from domestic sources such as hatcheries, poultry farms, egg product factories, homes and restaurants. Eggshell calcium is a good source of dietary calcium and excellent replacement material for important crustacean shells Suguroet al.,(2000). Moreover, calcium from the crushed eggshell powder was absorbed easier than commercial $\mathrm{CaCO}_{3}$ in the rat small intestine Swiatkiewiczet al.,(2015), and readily soluble in gastric juiceBradauskienéet al., (2016). 
Rehab H. Gab-Allah and Heba A. Shehta

Vitamin $D$ is an essential fat-soluble vitamin needed for efficient calcium absorption. The deficiency of vitamin $D$ has been related to hypertension, diabetes, metabolic syndrome, cancer, autoimmune, and infectious diseases (Ferguson et al., 2015; Holick and Chen, 2008).It is synthesized when the body is exposed to sunlight or after the consumption of fortified foods and supplements. Only a few foodstuffs naturally contain it, and these are mainly of animal origin such as egg yolk, fish and liver. Egg yolk contains high biological value of proteins and other nutrients such as other vitamins, minerals, essential fatty acids and phospholipids Anton (2013).

Date syrup is a product obtained from a matured product with about $67-72 \%$ solid concentration consisting of $95 \%$ reducing sugar (Mohamed and Ahmed, 1981and Rofehgari-Nejadet al.,2010). Date syrup is a high energy food rich in carbohydrate, a good source of minerals; but it also contains a very complex mixture of other saccharides, amino and organic acids, polyphenols and carotenoids Abbes et al.,(2013). The ingredients of date syrup depend on the type of date, but generally date syrup contains fructose, glucose, moisture and a small amount of sucrose, protein, pectin, and calcium Khosravanipouret al.,(2011).Date syrup is used in the preparation of some traditional and industrial foods (Mohamed and Ahmed, 1981 and Rofehgari-Nejadet al., 2010).It is a natural sweetener that is a suitable ingredient to be used in the formulation of food products in order to improve the nutrient properties. The Date syrup is directly consumed or used as an ingredient in some food formulation such as ice cream products, drink, confectionery, bakery products, sesame paste/date syrup blends, jam and some other Barreveld, (1993). 
Egyptian J. of Nutrition Vol. XXXV No. 2 (2020)

Some Studies have been done on using date syrup as a flavor in dairy products. The result of these studies have shown that low-fat cow milk prepared with palm syrup and fermented products prepared from milk being flavored with date syrup, led to good outcomes Moneibet al., (1999).

The aim of the research is to produce a healthy and nutritious drink by recycling some of the nutritional secondary by-products.

\section{Materials and methods}

\section{Materials}

Milk, eggs, dibs (as sweetener) and vanilla were purchased from the local market of Cairo, Egypt. Bifidobacterium animals ssp. lactis $\mathrm{Bb}-12 \AA$ was supplied by Chr . Hansen Inc . (Hoersholm,Denmark) . Carboxy methylcellulose (CMC) was obtained from Misr Food Additives-MIFAD.

All the materials were made available in the laboratory. Fresh cheese whey as obtained from the manufacturing of curd cheese was used as raw material for the beverage preparation. The eggs were cleaned by dusting, washing and allowed to dry. They were carefully deshelled and separated as egg white liquid and egg yolk liquid. The egg yolk homogenized with a metal whisk and dried at $45 \stackrel{\circ}{\mathrm{C}}$ for $5 \mathrm{~h}$ and allowed to cool. The egg yolk flakes was scooped, milled and sieved with a $0.09 \mathrm{~mm}$ size mesh according to Kumaravelet al., (2012).Theeggshellswithout membranes were boiled for $20 \mathrm{~min}$, then air dried, ground to a powder using a kitchen grinder and sieved to a fine powder by using a $0.09 \mathrm{~mm}$ size meshas described by Fred et al.,(2006).Table1, shows the average composition of all ingredients used in the present study. 
Rehab H. Gab-Allah and Heba A. Shehta

Table 1. Chemical composition of Sweet whey, Eggshell, Egg yolk and Date syrup (Dibs)

\begin{tabular}{l|c|c|c|c}
\hline Content & Sweet whey & Eggshell & Egg yolk & Dibs \\
\hline Total solids (\%) & 6.74 & 97.8 & 95.69 & 76.5 \\
\hline Protein (\%) & 0.96 & 2.3 & 32.2 & 0.95 \\
\hline Fat (\%) & 0.1 & - & 50 & 2.10 \\
\hline Carbohydrate (\%) & 4.93 & - & 8.1 & 71.88 \\
\hline Ash (\%) & 0.75 & 95.5 & 5.39 & 1.57 \\
\hline
\end{tabular}

\section{Preparation of fermented beverages}

After blending the ingredientsthe amount of eggshell (containing $39 \%$ calcium), egg yolk (containing $6.8 \mu$ vitamin D), CMC and vanilla $1 \%, 0.1 \%, 0.01 \%)$ respectively with sweet whey, the beverage waspasteurized at $80 \stackrel{\circ}{\circ}$ for $15 \mathrm{~min}$, cooled down to $40^{\circ} \mathrm{C}$ and inoculated with Direct Vat Set type Bb-12 culture (CHRHansen, Denmark) containingBifidobacteriumanimals ssp. lactis. then incubated at $37{ }^{\circ} \mathrm{C}$ for $8 \mathrm{~h}$ and cooled to $25 \stackrel{\circ}{\circ}$ C.Dibsas a sweetenerwere added in different proportions such asT1( 10\%), T2 $(12.5 \%)$ and $\mathrm{T} 3(15 \%)$ to fermented whey, distributed into sterile plastic bottles $(250 \mathrm{ml})$ and then stored at $4 \pm 1^{\circ} \mathrm{C}$ (the resulting mixture were formulated under aseptic condition).

\section{Analytical methods}

All the chemical analysis viz. moisture, fat, total nitrogen, ash and minerals of fermented whey beverages and content of raw materials e.g. whey, date syrup, egg yolk powder (EYP) and eggshell

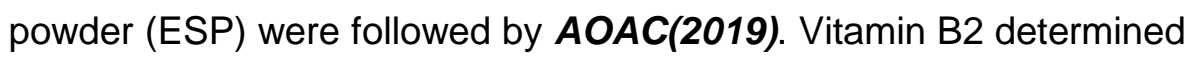
according toDanish Official (1996). Vitamin D determined according to Danish Official (2001). The pH value was measured using Lab. $\mathrm{pH}$ meter with a combined electrode, Hanna digital $\mathrm{pH}$ meter. The viscosity was measured by Brookifield DV- III viscometer using spindle SC4-21 at rpm 20. The temperature was maintained at $25^{\circ} \mathrm{C}$ and viscosity value was expressed in centipoises (cp). 
Egyptian J. of Nutrition Vol. XXXV No. 2 (2020)

Microbiological analysis

Bifidobacterium animals ssp. lactis was enumerated using MRS agar media after the incubation at $37^{\circ} \mathrm{C}$ for $72 \mathrm{~h}$. as reported by Dave and Shah, (1996).

Molds \& Yeasts were determined according to Standard Methods for Examination of Dairy ProductsAPHA (1994). Coliform bacteria were enumerated according to Harrigan and McCance, (1996) using Violet Red Bill Agar (VRBA). The plates were incubated at $37^{\circ} \mathrm{C}$ for $48 \mathrm{hr}$. Staphylococcus spp. and Salmonella spp. were detected according to methods recommended by ICMSF (1996).

\section{Color analysis}

Color parameters $L^{*}$ (lightness or brightness), $a^{*}$ (redness or greenness), and $b^{*}$ (yellowness or blueness) asdeterminedby CIElab color scale (Hunter, LabScan XE-Reston VA, USA) were measured using a Spectro colorimeter Wei et al.,(2012)

\section{Sensory evaluation}

Expert judges and consumers were selected from a staff member of theDairy Technology Department, Food Technology Research Institute,Giza, Egypt to evaluate the texture, flavor and overall acceptability of thefermented whey beverages. They scored the sample on the basis of a nine-point hedonic scale, ranging from like extremely $=9$ through like or dislike $=5$ to dislike extremely $=1$ as described by Lim J., (2011).

\section{Statistical analysis}

The data obtained (mean of three replicates) were statistically analyzed according to the statistical analyses system user's guide SAS (2004).Analysis of variance (ANOVA) and Duncan's multiple 


\section{Rehab H. Gab-Allah and Heba A. Shehta}

comparison procedure were used to compare the means. A probability of $p<0.05$ was used to establish statistical significance.

\section{Results and Discussion}

\section{Compositional analysis}

Data in Table 2 indicated that, the sweetening using dibs led to a significant difference in total solids and carbohydrates of fermented whey beverages due to addition of different levels of dibs. It confirmed that, total solids and carbohydrates increased significantly $(p<0.05)$ as the level dibs increased, due to the high carbohydrate content of dibs. The obtained results indicated the, neither protein, fat nor ash contents were influenced significantly at any level of dibs.Regarding the minerals and vitamins contents of fermented whey beverages, data stated that no significant differences ( $p>0.05)$ in the minerals and vitamins contents between treatments. Furthermore, the fermented wheybeverage fortified with levels of dibs was rich in minerals because data syrup is a good source of minerals Abbes et al., (2013).Also it is obvious from data in Table 2 that, these results are consistent with what the WHO/FAO has recommended for vitamin B2 daily intake. 
Egyptian J. of Nutrition Vol. XXXV No. 2 (2020)

Table 2:Chemical analysis of fermented whey beverages

\begin{tabular}{l|c|c|c}
\hline & \multicolumn{3}{|c}{ Treatments } \\
\hline Content & $\mathrm{T}_{1}$ & $\mathrm{~T}_{2}$ & $\mathrm{~T}_{3}$ \\
\hline Total solids (\%) & $16.0^{\mathrm{c}}$ & $17.7^{\mathrm{b}}$ & $19.5^{\mathrm{a}}$ \\
\hline Protein $(\%)$ & 1.5 & 1.49 & 1.48 \\
\hline Fat $(\%)$ & 0.8 & 0.85 & 0.9 \\
\hline Carbohydrate (\%) & $11.84^{\mathrm{c}}$ & $13.52^{\mathrm{b}}$ & $15.29^{\mathrm{a}}$ \\
\hline Ash $(\%)$ & 1.86 & 1.84 & 1.83 \\
\hline $\mathrm{Ca}(\mathrm{mg} / 100)$ & 317.93 & 317.81 & 317.15 \\
\hline $\mathrm{P}(\mathrm{mg} / 100)$ & 213.71 & 213.67 & 213.63 \\
\hline $\mathrm{K}(\mathrm{mg} / 100)$ & 766.72 & 766.90 & 766.91 \\
\hline $\mathrm{Mg}(\mathrm{mg} / 100)$ & 28.21 & 28.34 & 28.52 \\
\hline $\mathrm{Na}(\mathrm{mg} / 100)$ & 58.59 & 58.92 & 58.95 \\
\hline Zn $(\mathrm{mg} / \mathrm{kg})$ & 9.190 & 9.200 & 26.057 \\
\hline $\mathrm{Mn}(\mathrm{mg} / \mathrm{kg})$ & 26.054 & 26.054 & 152.95 \\
\hline Fe $(\mathrm{mg} / \mathrm{kg})$ & 152.66 & 152.78 & 1.7 \\
\hline Riboflavin $(\mathrm{mg})$ & 1.5 & 1.7 & 0.65 \\
\hline Vitamin D $(\mu \mathrm{g})$ & 0.66 & 0.66 & \\
\hline Means with different & & & \\
\hline
\end{tabular}

\section{Microbiological quality}

Table 3 represented the changes in logarithm numbers of Bifidobacteriumlactis viable count of various concentrations of dibs in fermented whey beverages. The count of Bifidobacteriaremainedhigh until the second week and began to diminish thereafter. Viable counts were gradually decreased with the prolongation of storage periods. The difference in the count of Bifidobacteriumlactiswas not significant ( $p>0.05)$ between $T_{2}$ and $T_{3}$. These results agree with the trends reviewed by Al-Otaibiet al.,(2013) who showed that the addition of dibs can safely be used as sweeteners for the fermented milk in the presence of the probiotic bacteria. Results also indicated that the viable counts of $\mathrm{Bb}-12$ were maintained at an acceptable level to be consideredas a functional food $\left(10^{6}-10^{7} \mathrm{CFU} / \mathrm{g}\right)$, which is the recommended minimum daily intakeSheehan et al., (2007)

Molds \& yeasts, Staphylococcus spp.,Salmonella spp., sporformersand coliformswere notdetected in all fermented whey 


\section{Rehab H. Gab-Allah and Heba A. Shehta}

treatments, either when fresh or during the storage period. This may be due to the high hygienic conditions during production and the production of antimicrobial agents by bifidobacteria.

Table 3: Viability of Bifidobacteriumlactis (log CFU/ml) in fermented whey beverage during cold storage at $4 \pm 1^{\circ} \mathrm{C}$

\begin{tabular}{c|c|c|c}
\hline & \multicolumn{3}{|c}{ Treatments } \\
\hline Cold storage (days) & $\mathrm{T}_{1}$ & $\mathrm{~T}_{2}$ & $\mathrm{~T}_{3}$ \\
\hline Fresh & $6.92^{\mathrm{b}, \mathrm{A}}$ & $7.53^{\mathrm{a}, \mathrm{A}}$ & $7.56^{\mathrm{a}, \mathrm{A}}$ \\
\hline 7 & $6.83^{\mathrm{b}, \mathrm{A}}$ & $7.52^{\mathrm{a}, \mathrm{A}}$ & $7.52^{\mathrm{a}, \mathrm{A}}$ \\
\hline 14 & $6.53^{\mathrm{b}, \mathrm{AB}}$ & $7.40^{\mathrm{a}, \mathrm{AB}}$ & $7.43^{\mathrm{a}, \mathrm{AB}}$ \\
\hline 21 & $6.10^{\mathrm{b}, \mathrm{B}}$ & $6.90^{\mathrm{a}, \mathrm{B}}$ & $6.92^{\mathrm{a}, \mathrm{B}}$
\end{tabular}

Small letters in superscript $(a, b, .$.$) describe the significance for the factor "dibs$ level. While Capital letters $(A, B, .$.$) in superscript describe the significance of the$ storage period. Means followed by the same letter do not differ significantly $(\mathrm{P}>0.05)$. 
Egyptian J. of Nutrition Vol. XXXV No. 2 (2020)

\section{pH values and viscosity}

As appears from Table 4, the addition of dibs caused an insignificant decrease in $\mathrm{pH}$ value $(\mathrm{p}>0.05)$, the decrease was proportional to the addition ratio. However, the decreasing in $\mathrm{pH}$ values was significantly after 2 weeks $(p \leq 0.05)$. This may be attributed to the high concentration of components i.e. (immunoglobulin, lysozyme, glycomacropeptide and lactoferrin) in whey.

Results given in the same table indicated that the viscosity increasedslowly with addition ratio of dibs. Also, results in Table 4 show that viscosity values, in all treatments were increased in significant differences $(p<0.05)$ with the prolong of storage period. That could be due to the dietary fiber content (DF) in dibs that had desirable functional properties, such as providing texture, gelling, thickening, emulsification and stabilization in DF enriched foods Nelson(2001). 


\section{Rehab H. Gab-Allah and Heba A. Shehta}

Table 4: $\mathrm{pH}$ values and viscosity of fermented whey beverages during cold storage at $4 \pm 1^{\circ} \mathrm{C}$

\begin{tabular}{c|c|c|c|c}
\hline & & \multicolumn{3}{|c}{ Treatments } \\
\hline & Cold storage (days) & $\mathrm{T}_{1}$ & $\mathrm{~T}_{2}$ & $\mathrm{~T}_{3}$ \\
\hline $\mathrm{pH}$ & Fresh & $6.49^{\mathrm{a}, \mathrm{A}}$ & $6.43^{\mathrm{ab}, \mathrm{A}}$ & $6.40^{\mathrm{b}, \mathrm{A}}$ \\
\hline & 7 & $6.41^{\mathrm{a}, \mathrm{A}}$ & $6.38^{\mathrm{ab}, \mathrm{A}}$ & $6.33^{\mathrm{b}, \mathrm{A}}$ \\
\hline & 15 & $6.29^{\mathrm{a}, \mathrm{B}}$ & $6.20^{\mathrm{ab}, \mathrm{B}}$ & $6.17^{\mathrm{b}, \mathrm{B}}$ \\
\hline & 21 & $6.20^{\mathrm{a}, \mathrm{C}}$ & $6.14^{\mathrm{ab}, \mathrm{C}}$ & $6.00^{\mathrm{b}, \mathrm{C}}$ \\
\hline Viscosity (cp) & Fresh & $10^{\mathrm{c}, \mathrm{D}}$ & $15^{\mathrm{b}, \mathrm{D}}$ & $30^{\mathrm{a}, \mathrm{D}}$ \\
\hline & 7 & $43.33^{\mathrm{c}, \mathrm{C}}$ & $65^{\mathrm{b}, \mathrm{C}}$ & $85^{\mathrm{a}, \mathrm{C}}$ \\
\hline & 14 & $80^{\mathrm{c}, \mathrm{B}}$ & $110^{\mathrm{b}, \mathrm{B}}$ & $133^{\mathrm{a}, \mathrm{B}}$ \\
\hline & 21 & $150^{\mathrm{c}, \mathrm{A}}$ & $210^{\mathrm{b}, \mathrm{A}}$ & $270^{\mathrm{a}, \mathrm{A}}$ \\
\hline
\end{tabular}

Small letters in superscript $(a, b, .$.$) describe the significance for the factor "dibs level. While Capital letters (A$, $B, .$.$) in superscript describe the significance of the storage period. Means followed by the same letter do not$ differ significantly $(P>0.05)$.

\section{Color parameters:}

Whey beverages colors consider as an important factor for consumer acceptance. As seen in Table 5 the lightness (L-values) was markedly affected by the addition of dibs. The lightness degree of $T_{3}$ was higher than that of $T_{1}$ untilat the end of the storage period (21 days). This tendency was recorded during the storage period. The same tendency was noticed for their redness(a-value) and yellowness ( $b$-value) $(p<0.05)$ by increasing the amount of dibs addition. Changes in color characteristics influenced by the addition of ingredients were statistically significant $(P<0.05)$, but not significant enough to have a negative effect on the product color changes.

\section{Sensory evaluation}

Sensory characteristics of fermented whey beverages with different dibs ratio during storage period are presented in Table 6. In general, sensory analysis of the treatments showed a significant difference $(P<0.05)$ among the treatments for color, consistency, flavorand overall acceptability. A visual evaluation of the samples by 
Egyptian J. of Nutrition Vol. XXXV No. 2 (2020)

the panel showed that the effect of a different ration of dibs on the samples color characteristics was significant $(P<0.05)$. Also, $T_{2}$ and $T_{3}$ exhibited higher consistency scores than $T_{1}$, the difference being significant $(P<0.05)$. As scores listed in Table 6 , the flavor of whey beverages become more preferable to panelists with adding dibs in the blend up to $15 \%$ compared to $10 \%$. The negative effect of added ingredients on flavor was noticed after 7 days. The sensory quality attributes of all treatments decreased after 14 days. These data accordance withSasi(2015).It is evident from Table (6) that, treatment $\mathrm{T}_{2}$ gained significantly the highest average value of overall acceptabilitycompared with other treatments.

The overall acceptability of fermented whey beverage blending with $12.5 \%$ dibs $\left(\mathrm{T}_{2}\right)$ was found to be superior. National consumer inclinations could also play an important role in sensory analysis. There are not too many whey-based drink products in the Egyptian market and there is no convention of drinking whey and whey-based beverages in the Egypt Republic. These products are more widely available and accepted by people in countries such as Germany, Austria, and Switzerland where there is a longer tradition of whey consumption. 
Rehab H. Gab-Allah and Heba A. Shehta

Table 5: Color parameters of fermented whey beveragesduring cold storage at $4 \pm 1^{\circ} \mathrm{C}$

\begin{tabular}{l|l|l|l|l}
\hline & \multicolumn{2}{|l}{} & \multicolumn{2}{l}{ Treatments } \\
\hline & $\begin{array}{l}\text { Cold storage } \\
\text { (days) }\end{array}$ & $\mathrm{T}_{1}$ & $\mathrm{~T}_{2}$ & $\mathrm{~T}_{3}$ \\
\hline $\mathrm{L}$ & Fresh & $51.45^{\mathrm{a}, \mathrm{A}}$ & $49.82^{\mathrm{ab}, \mathrm{A}}$ & $47.18^{\mathrm{b}, \mathrm{A}}$ \\
\hline & 7 & $51.33^{\mathrm{a}, \mathrm{A}}$ & $49.51^{\mathrm{ab}, \mathrm{A}}$ & $47.00^{\mathrm{b}, \mathrm{A}}$ \\
\hline & 14 & $51.20^{\mathrm{a}, \mathrm{AB}}$ & $49.18^{\mathrm{ab}, \mathrm{AB}}$ & $46.87^{\mathrm{b}, \mathrm{AB}}$ \\
\hline & 21 & $51.11^{\mathrm{a}, \mathrm{B}}$ & $49.02^{\mathrm{ab}, \mathrm{B}}$ & $46.69^{\mathrm{b}, \mathrm{B}}$ \\
\hline $\mathrm{A}$ & Fresh & $5.01^{\mathrm{b}, \mathrm{B}}$ & $5.17^{\mathrm{ab}, \mathrm{B}}$ & $5.35^{\mathrm{a}, \mathrm{B}}$ \\
\hline & 7 & $5.17^{\mathrm{b}, \mathrm{AB}}$ & $5.23^{\mathrm{ab}, \mathrm{AB}}$ & $5.40^{\mathrm{a}, \mathrm{AB}}$ \\
\hline & 14 & $5.21^{\mathrm{b}, \mathrm{A}}$ & $5.31^{\mathrm{ab}, \mathrm{A}}$ & $5.49^{\mathrm{a}, \mathrm{A}}$ \\
\hline $\mathrm{B}$ & 21 & $5.29^{\mathrm{b}, \mathrm{A}}$ & $5.43^{\mathrm{ab}, \mathrm{A}}$ & $5.62^{\mathrm{a}, \mathrm{A}}$ \\
\hline & Fresh & $18.19^{\mathrm{b}, \mathrm{B}}$ & $18.43^{\mathrm{ab}, \mathrm{B}}$ & $18.72^{\mathrm{a}, \mathrm{B}}$ \\
\hline & 7 & $18.24^{\mathrm{b}, \mathrm{AB}}$ & $18.49^{\mathrm{ab}, \mathrm{AB}}$ & $18.79^{\mathrm{a}, \mathrm{AB}}$ \\
\hline & 14 & $18.30^{\mathrm{b}, \mathrm{A}}$ & $18.57^{\mathrm{ab}, \mathrm{A}}$ & $18.88^{\mathrm{a}, \mathrm{A}}$ \\
\hline
\end{tabular}

Small letters in superscript $(a, b, .$.$) describe the significance for the factor "dibs level. While Capital letters (A,$ $B, .$.$) in superscript describe the significance of the storage period. Means followed by the same letter do not$ differ significantly $(P>0.05)$.

Table 6: Sensory evaluation of fermented whey beverages duringcold storage at $4 \pm 1^{\circ} \mathrm{C}$

\begin{tabular}{l|c|c|c|c}
\hline & & \multicolumn{3}{|c}{ Treatments } \\
\hline & $\begin{array}{c}\text { Cold storage } \\
\text { (days) }\end{array}$ & $\mathrm{T}_{1}$ & $\mathrm{~T}_{2}$ & $\mathrm{~T}_{3}$ \\
\hline Color and Appearance & Fresh & $7.13^{\mathrm{b}, \mathrm{A}}$ & $7.82^{\mathrm{a}, \mathrm{A}}$ & $7.81^{\mathrm{a}, \mathrm{A}}$ \\
\hline & 7 & $7.00^{\mathrm{b}, \mathrm{B}}$ & $7.67^{\mathrm{a}, \mathrm{B}}$ & $7.55^{\mathrm{a}, \mathrm{B}}$ \\
\hline & 14 & $6.81^{\mathrm{b}, \mathrm{BC}}$ & $7.50^{\mathrm{a}, \mathrm{BC}}$ & $7.50^{\mathrm{a}, \mathrm{BC}}$ \\
\hline & 21 & $6.55^{\mathrm{b}, \mathrm{C}}$ & $7.44^{\mathrm{a}, \mathrm{C}}$ & $7.36^{\mathrm{a}, \mathrm{C}}$ \\
\hline Consistency & Fresh & $7.19^{\mathrm{b}, \mathrm{B}}$ & $7.28^{\mathrm{a}, \mathrm{B}}$ & $7.30^{\mathrm{a}, \mathrm{B}}$ \\
\hline & 7 & $7.53^{\mathrm{b}, \mathrm{A}}$ & $7.62^{\mathrm{a}, \mathrm{A}}$ & $7.69^{\mathrm{a}, \mathrm{A}}$ \\
\hline & 14 & $7.21^{\mathrm{b}, \mathrm{BC}}$ & $7.37^{\mathrm{a}, \mathrm{BC}}$ & $7.40^{\mathrm{a}, \mathrm{BC}}$ \\
\hline Flavor & 21 & $7.00^{\mathrm{b}, \mathrm{C}}$ & $7.17^{\mathrm{a}, \mathrm{C}}$ & $7.29^{\mathrm{a}, \mathrm{C}}$ \\
\hline & Fresh & $7.0^{\mathrm{b}, \mathrm{B}}$ & $7.5^{\mathrm{a}, \mathrm{B}}$ & $7.3^{\mathrm{a}, \mathrm{B}}$ \\
\hline & 7 & $7.5^{\mathrm{b}, \mathrm{A}}$ & $8.2^{\mathrm{a}, \mathrm{A}}$ & $8.1^{\mathrm{a}, \mathrm{A}}$ \\
\hline Over all acceptability & 14 & $6.9^{\mathrm{b}, \mathrm{BC}}$ & $7.8^{\mathrm{a}, \mathrm{BC}}$ & $7.7^{\mathrm{a}, \mathrm{BC}}$ \\
\hline & 21 & $6.4^{\mathrm{b}, \mathrm{C}}$ & $7.23^{\mathrm{a}, \mathrm{C}}$ & $7.21^{\mathrm{a}, \mathrm{C}}$ \\
\hline & Fresh & $7.21^{\mathrm{b}, \mathrm{C}}$ & $7.7^{\mathrm{a}, \mathrm{B}}$ & $7.63^{\mathrm{a}, \mathrm{B}}$ \\
\hline & 7 & $7.45^{\mathrm{b}, \mathrm{A}}$ & $8.10^{\mathrm{a}, \mathrm{A}}$ & $7.94^{\mathrm{a}, \mathrm{A}}$ \\
\hline & 14 & $7.1^{\mathrm{b}, \mathrm{BC}}$ & $7.6^{\mathrm{a}, \mathrm{BC}}$ & $7.48^{\mathrm{a}, \mathrm{BC}}$ \\
\hline
\end{tabular}

Small letters in superscript $(a, b, .$.$) describe the significance for the factor "dibs level. While Capital letters (A,$ $B, .$.$) in superscript describe the significance of the storage period. Means followed by the same letter do not$ differ significantly $(\mathrm{P}>0.05)$. 
Egyptian J. of Nutrition Vol. XXXV No. 2 (2020)

\section{Conclusion}

It can be concluded that whey based drink can be prepared by using $12.5 \%$ of dibs with the highest consumer acceptability as compared to the other treatment. Whey contains about half of the milk solids and addition of eggshell, egg yolk, dibs in the preparation of fermented whey drink increased the health and nutritional value. One cup of the produced drink $250 \mathrm{ml}$ will cover daily calcium requirement of an adult person. 
Rehab H. Gab-Allah and Heba A. Shehta

\section{References}

Abbes, F., Kchaou, W., Blecker, C., Ongena, M., Lognay, G., Attia, H. and Besbes, S. (2013):

Effect of processing conditions on phenolic compounds \& antioxidant properties of date syrup". Industrial crop \& product.44, 634 .

Al-Otaibi, M.M.; Saleha, F.A. and Al-Obaid, R. (2013):

Effect of date syrup (dips) on growth and survival of probiotic bacteria in milk. Int. J. Dairy Sci., 8: 12.

Anton, M. (2013):

Egg yolk: structure, functionalities and processes. J. Sci. Food Agri., 93: 2871.

AOAC. (2019):

Association of Official Analytical Chemists. Official Method of Analysis. (21 $1^{\text {th }}$ Ed.). Benjamin Franklin Station Washington, D.C., USA.

APHA, American Public Health Association.(1994):

Standard Method of the Examination of Dairy products 16th Ed.., Washington, USA.

Barreveld, W. H. (1993):

Date palm products. Nume'roAgricole 101 de bulletin de services de la FAO. 
Egyptian J. of Nutrition Vol. XXXV No. 2 (2020)

Bradauskienė V., Moščenkova E., Zymonaitė K. (2016):

Scientific assumptions on use of eggshell powder as food enrichment with calcium. In: Safe and healthy food challenges and practical experience: proceedings of the conference, p. 11-17

Castro, J.,Tornadijo,M. ,Fresno,J.,and Sandoval, H. (2015):

Biocheese: a food probiotic carrier. Biomed.Res.Int., 723056.doi:10.1155/2015/723056

Danish Official. (1996):

Vitamin B1 and B2 HPLC method No. AB 189.2-national food agency of Denmark.

Danish Official. (2001):

Determination of vitamin D in food and feed by HPLC., CEN, 12821 , food stuffy.

Dave, R.I.and N.P. Shah. (1996):

Evaluation of media for selective enumeration of Streptococcus thermophilus, Lactobacillus delbrueckii ssp. bulgaricus, Lactobacillus acidophilus and bifidobacteria. J. Dairy Sci., 79: 1529.

Dri N., Brun L., Di Loreto V., Lupo M., Rigalli A. (2011):

Study of the composition of the eggshell. A low cost calcium supplement. Bone, Vol. 49 (6), p. 1381-1388

Durham R.J., Hourigan J., Sleigh R.W and Jhonsen R.L. (1997):

Whey fraction: wheying up consequences. Food Aust 49: 460. 


\section{Rehab H. Gab-Allah and Heba A. Shehta}

FAO/WHO. (2001):

Report of the Joint FAOMHO Expert Consultation on Evaluation of Health and Nutritional Properties of Probiotics in Food Including Powder Milk with Live Lactic Acid Bacteria. Rome: Food and Agriculture Organization of the United Nations.

Ferguson, L. R., Laing, B., Marlow, G., and Bishop, K. (2015):

The role of vitamin $D$ in reducing gastrointestinal disease risk and assessment of individual dietary intake needs: Focus on genetic and genomic technologies. Journal of Functional Foods, 13, 300-307.

Fred S., Wang P., Weatherspoon J and Mead L. (2006):

Method of producing eggshell powder, US 20060062857 A1

Harrigan, W.F. and McCance, M.E. (1996):

Laboratory Method in Microbiology. Academic press, London and New York, 292-293.

Holick, M. F., and Chen, T. C.(2008):

Vitamin $D$ deficiency is a worldwide problem with health consequences. American Journal of Clinical Nutrition, 87(suppl), 1080S-6S.

ICMSF, International Commission on Microbiological Specification for Food. (1996):

Micro-organisms in Food Microbiological Specification of Food Pathogens. Back Academic and Professional. T.A. Roberts, A.C. Baird- Parker and R.B . (eds). 
Egyptian J. of Nutrition Vol. XXXV No. 2 (2020)

Jacqmain, M., Doucet, E., Despres, J. P., Bouchard, C., and Tremblay, A. (2003):

Calcium intake, body composition, and lipoprotein-lipid concentration in adults. Amer. J. Clinical Nutri., 77:1448.

Khosravanipour, Mostafazadeh, A., Sarshar, M., Javadian, S., Zarefard, M. and AmirifardHaghighi, Z. (2011):

Separation of fructose \& glucose form date syrup using resin chromatographic method: Experimental data \&mathematical modeling, Separation \& purification technology, 79: 72.

Kumaravel, S.; Hema R. and Kamaleshwari A. (2012):

Effect of Oven drying on the nutritional properties of whole egg and its components. Intr. J. Food and Nutr. Sci., 1: 4.

Lim J. (2011):

Hedonic scaling: A review of methods and theory, Food Quality and Preference; 22:733.

Linares, D., Ross,P., and Stanton,C. (2016):

Beneficialmicrobes: the pharmacy in the gut. Bioengineered 7,11 .

Linares, D.M., Carolina Gómez, Erica Renes, José M. Fresno, María E. Tornadijo, R. P. Ross and Catherine Stanton. (2017):

Lactic acid bacteria and bifidobacteria with potential of design natural biofunctional health-promoting dairy foods. www.frontiesin.org. 


\section{Rehab H. Gab-Allah and Heba A. Shehta}

Lorenzen, J. K., and Astrup, A. (2011):

Dairy calcium intake modifies responsiveness of fat metabolism and blood lipids to a high-fat diet. British J. Nutri., 105:1823. DOI:10.1017/ S0007114510005581

Maria R. C., Antonio B., Leonardo P., Francesco P., and Milena S. (2014):

Comprehensive Reviews in Food Science and Food Safety .Vol.13.

Mohamed, M. and Ahmed, A. (1981):

Libyan date syrup (Rub-AL-Tamr). J. food sci., 46: 1162.

Moneib, A., EL-Sadak, G. and Farag, A. (1999):

Sterilized Flavored milk drinks: Date-flavored buffalo skim milk. Egyp. J. Dairy Sci., 2: 105.

Nelson, A. L. (2001):

High-Fiber Ingredients. Eagan press handbook series. St Paul, MN: Eagan Press, 2001.

Olgun O., Yildiz A. Ö., Cufadar Y. (2015):

The effects of eggshell and oyster shell supplemental as calcium sources on performance, eggshell quality and mineral excretion in laying hens. Indian J. Animal Res., Vol 49 : 205.

Rofehgari-Nejad, L., Pirrzifard, M., Asefi, N., Tabibi-Azar, M. and Ashrafi, R. (2010):

Comparative study of date syrup decolorization efficiency with ion exchange resins \& bone chart, Asian J. Chemi., 22: 16. 
Egyptian J. of Nutrition Vol. XXXV No. 2 (2020)

Sanguansri L., Augustin M. (2009):

Microencapsulation in functional food product development. In: Smith J, Charter E, editors. Functional food product development. New York, N.Y.: John Wiley \& Sons. p. 3.

\section{SAS.( 2004):}

Statistical Analysis System. SAS user's guide. Statistics. SAS Inst. Inc. Ed., Cary, NC, U.S.A.

Sasi, K. R. (2015):

Development, quality evaluation and shelf life studies of probiotic beverages using whey and aloe vera juice. J Food Process. Technol., 6:9.

Sheehan V., Ross P, and Fitzgerald G. (2007):

Assessing the acid tolerance and the technological robustness of probiotic cultures for fortification in fruit juices. Inn. Food Sci. Emerg. Technol., 8:279.

Sinha R., Radha C., Prakash J. and Kaul P. (2007):

Whey protein hydrolysates: functional properties, nutritional quality and utilization in beverage formulation. Food Chem 101: 1484.

Swiatkiewicz S, Amzewska-Wlosek A, Krawczyk J, Puchala M, Jözefiak D. (2015):

Effects in performance and eggshell quality of particle size of calcium sources in laying hens' diets with different $\mathrm{Ca}$ concentrations; Arch. Anim. Breed,; 58:301. 


\section{Rehab H. Gab-Allah and Heba A. Shehta}

Suguro N,Horiike S, Masuda Y, Kunou M, Kokubu T . (2000):

Bioavailability and commercial use of Eggshell calcium, membrane proteins and yolk Lecithin products. In j.s. Sim, S. Nakai and W. Guenter (Eds.), Egg Nutrition and Biotechnology, New York: CABI., 219-232.

Tamime,A., Saarela,M. ,KorslundSødergaard,A., Mistry,V. and Shah,N. (2005):

"Production and maintenance of viability of probioticmicroorganisms in dairy products," in Probiotic Dairy Products, ed. A. Y. Tamime (Oxford: BlackwellPublishingLtd),39-72.

Wei, S.; Ou L.; Luo M. and Hutchings J. (2012):

Optimization of food expectations using product colour and appearance. Food Qual. Preference. 23, 49.

\section{Wootton-Beard P.and Ryan L. (2011):}

Improving public health? The role of antioxidant-rich fruit and vegetable beverages. Food Res Int 44:3135. 
Egyptian J. of Nutrition Vol. XXXV No. 2 (2020)

مشروب شرش وظيفي جديد يحتوي علي الكالسيوم ودبس البلح

د/ رحاب حامد جاب الله *، د/ هبه عبد الفتاح شحته

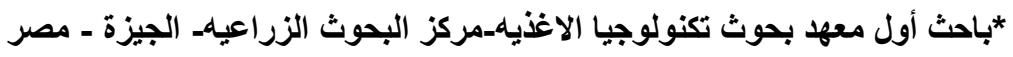

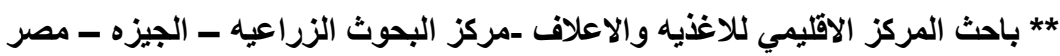

$$
\text { الملخص العربى }
$$

تهدف هذه الدراسة الى استخدام المنتجات الثانوية الغذائية التي لها خصائص وظيفية

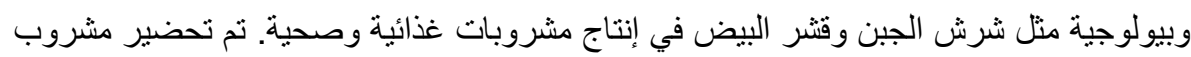

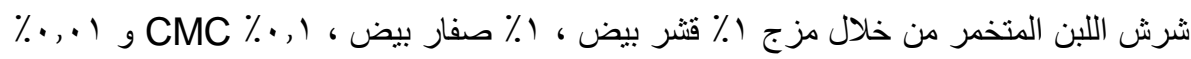
فانيليا مع شرش اللبن الحلو. والتلقيح ب-Bifidobacterium animals ssp. LactisBb

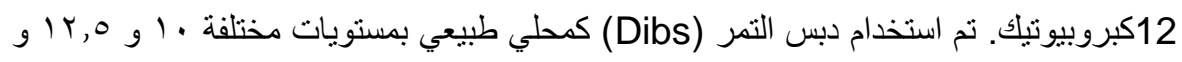
1\% حجم / حجم من المشروب وتم تحليله من حيث الخصائص الكيميائية ،الفيزيائية

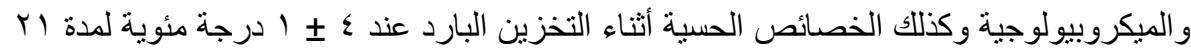
يومًا ، أوضحت النتائج التي تم الحصول عليها أن قيم الأس الهيدروجيني انخفضت التئ تدريجيًا خلال

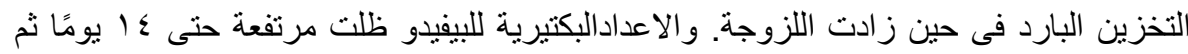

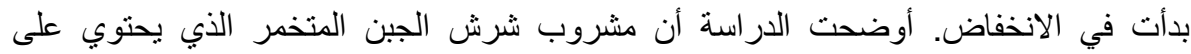

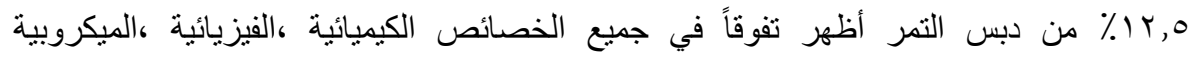
و الخصائص الحسية مقارنة بالمعاملات الأخرى.ويعتبر مشروب مرتفع القين القيمة الغذائيه . 